\title{
BANSKOBYSTRICKÝ STREDOVEKÝ A NOVOVEKÝ VODOVOD VO SVETLE ARCHEOLOGICKÝCH NÁLEZOV A PÍSOMNÝCH PRAMEŇOV
}

\author{
MARTA MÁCELOVÁ
}

\begin{abstract}
Abstrakt: Príspevok sumarizuje výsledky archeologických výskumov v Banskej Bystrici, počas ktorých boli zistené relikty stredovekých a novovekých vodovodných zariadení na rozvod, zachytávanie a odvádzanie vody v banskom meste. Opierajúc sa o archeologické i písomné pramene sa snaži o rekonštrukciu vodovodnej siete. Príspevok dokladá dôkazy o technickej vyspelosti stredovekých majstrov, ktorí boli schopní vyhotovit' dômyselné zariadenie, zabezpečujúce potrebné množstvá vody pre každodenný život mesta Banská Bystrica.
\end{abstract}

Kl'účové slová: stredovek - novovek - studňa-drevený vodovod-kanalizácia.

The Medieval and Modern-Age Water Supply System in Banská Bystrica in the Light of Archaeological Finds and Written Sources

Abstract: This contribution summarizers the results of archaeological research in Banská Bystrica, in the course of which relics of medieval and modern-age water supply devices for the distribution, retaining and drainage of water in this mining town were unearthed. Based on archaeological and written sources, the article reconstructs the water supply system. It presents evidence of the superb technical skills of medieval master builders who could design ingenious devices providing the supply of water necessary for everyday life in the town of Banská Bystrica.

Key words: Middle Ages - modern age - well - wooden water supply system - sewage system.

\section{Úvod}

Významné banské mesto Banská Bystrica, ležiace na sútoku rieky Hron a potoka Bystrica, dostalo v roku 1255 od panovníka Bela IV. výsady slobodného královského mesta. Tie panovník udelil nemeckým kolonistom (hospitibus nostris de nova villa Bystrice) na ich žiadost' (CDS1 II, 1987, 340-341 č. 491). Bystrica ležala na križovatke krajinských ciest vedúcich z juhu od Zvolena na sever do Turca a v smere od západu na východ údolím Hrona (CDS1 II, 1987, 243 č. 349; 341 č. 491). Dôkazom existencie starej slovanskej osady na pravom brehu Hrona je nepočetná, ale výrazná slovanská keramika z 9. storočia, ktorá sa našla v híbke $110-115 \mathrm{~cm}$ pod povrchom, v kultúrnej vrstve porušenej stredovekou zástavbou renesančného domu počas archeologického výskumu v dvornom trakte na Námestí SNP č. 3 (Mácelová 1996, 425). F. Uličný $(2006,9)$ predpokladá, že dedinu Bystrica založili slovenskí poddaní pravdepodobne pred 11. storočím, v nej sa ,okolo roku 1200 samovol’ne udomácnila zvyklost’ trhu“, ktorá prilákala prist’ahovalcov z Nemecka, prechodne žijúcich vo Zvolene. Príchod nemeckých kolonistov (Sasov) zefektívnil banskú t’ǎ́bu vd’aka dokonalejším znalostiam dobývania rúd (Albertová 2009, 58). Mestotvorný proces urýchlili výsady z roku 1255 pre novousadlých, ale aj starousadlých obyvatel'ov Bystrice. Okrem úpravy právneho postavenia znamenali aj kvalitatívne zmeny v jej vývoji (Uličný 2006, 14).

\section{Zdroje vody}

Nárastom obyvatel'stva v mestách sa neustále zvyšoval dopyt po vode. Túto funkciu plnila riečna siet', ktorá sa okrem zdroja pitnej vody stala zdrojom úžitkovej vody a energie pre potreby remeselníckych dielní, ktoré boli na nej závislé. Vel'ké množstvo vody na prevádzku potrebovali aj mestské kúpele vznikajúce pri vodných tokoch, ktoré rovnaké množstvo odvádzali do odpadu (Petráň a kol. 1985, I (2), 538). Prvé verejné kúpele vznikali v Európe v 12. storočí (Goetz 2005, $35)$. Okrem tečúcej vody pri vodných tokoch sa využívala aj povrchová dažd’ová voda a v zime topiaci sa sneh. 


\section{Studne a cisterny}

Tam, kde neexistovali prírodné zdroje, budovali sa nádrže na zachytávanie vody: cisterny a studne, ktoré boli proti znečisteniu prekryté prístreškami. V mnohých mestách Európy sa stavali na verejných priestranstvách spoločné studne (Petráň a kol. 1985, I (2), 673). Mesto Levoča malo v 16. storočí strážcu studní - Wasserlöcherwächter (Slivka 1986, 65). Najviac poznatkov o stredovekých studniach, nádržiach na zachytávanie vody a vodovodných zariadeniach priniesli nálezy z archeologických výskumov stredovekých aglomerácií v Bratislave (Polla-Vallašek a iní 1991, 82, 83, 85, 124), Nitre (Habovštiak 1971, 113-114), Bardejove (Hanušin 1986), Banskej Bystrici (obr. 1; Mácelová 1997, 129; 1998, 112-113; 2004, 134; Hanuliak 2007; Miňo-Brezňanová-Fratričová 2008; Zachar 2009), Trnave (Mészárosová 1980, 141; 1980a, 46-47; Barteková 2012, 136-137), Prešove (Ďurišová 2013, 51), Kežmarku (Genersich 1804), Písku (Široký 2000, 384), Prahe (Huml 1975), Moste (Velímský 1976), Chebe (Šebesta 2009), Brne (Jordánková-Sulitková 1991), Olomouci (Široký 2000, 383), Kroměříži (Chybová 2009, 309-321), Jihlave (Hoffmann 1992, 93).

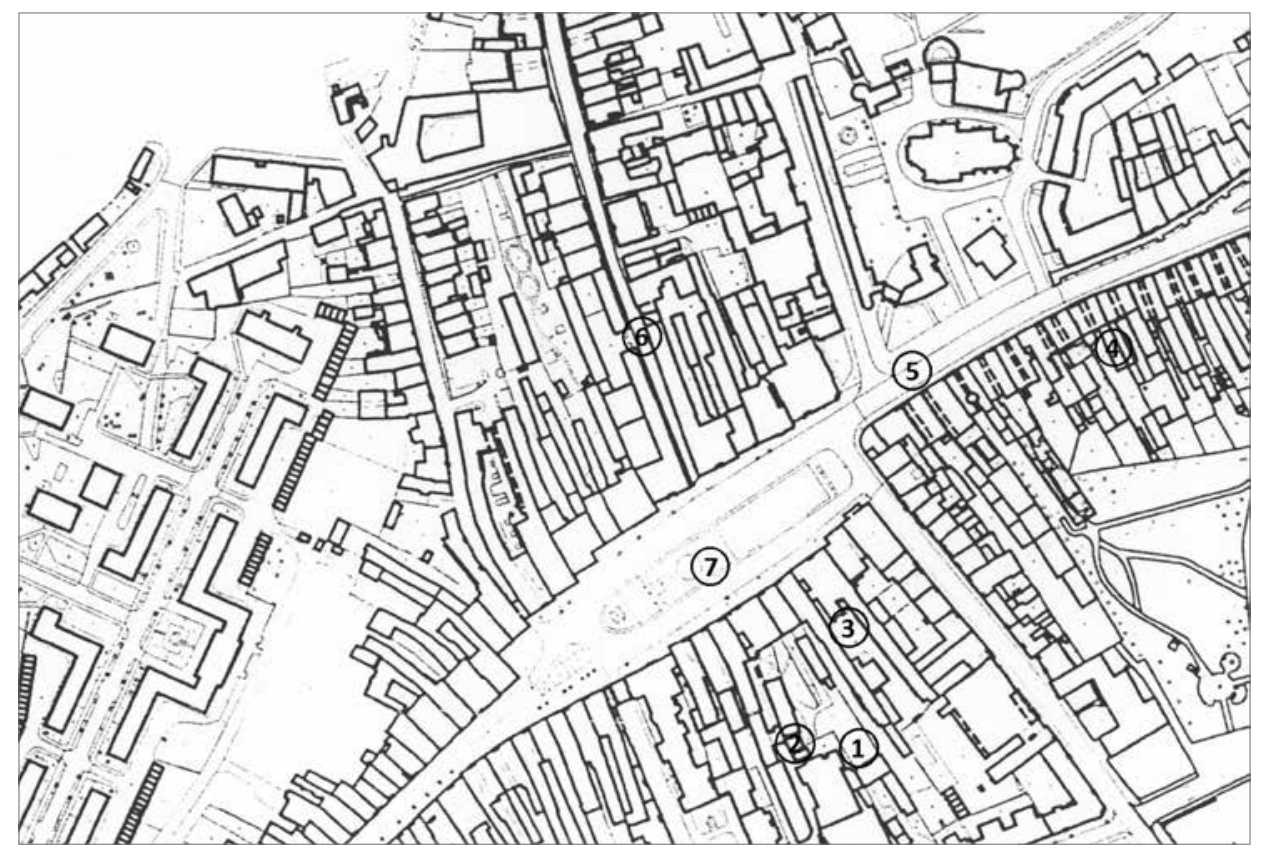

Obr. 1. Banská Bystrica. Výrez plánu Mestskej pamiatkovej rezervácie s vyznačenými archeologicky skúmanými lokalitami. 1 - Námestie SNP č. 3; 2 - Námestie SNP č. 4; 3 - Námestie SNP č. 1; 4 - Horná ulica č. 2-4; 5 - Námestie Š. Moysesa; 6 - Lazovná ulica; 7 - Námestie SNP.

Abb. 1. Banská Bystrica. Ausschnitt aus der Planskizze des Städtischen Denkmalschutzgebiets mit den untersuchten archäologischen Fundstellen. 1 - Platz des Slowakischen Nationalaufstandes Nr. 3; 2 - Platz des Slowakischen Nationalaufstandes Nr. 4; 3 - Platz des Slowakischen Nationalaufstandes Nr. 1; 4 - Obere Gasse Nr. 2-4; 5 -Štefan-Moyses-Platz; 6 - Badergasse; 7 - Platz des Slowakischen Nationalaufstandes.

Prvé súkromné studne v Európe sú datované do 12.-13. storočia a boli budované na dvoroch alebo v pivniciach. Verejné studne slúžili tým obyvatel'om na uhasenie smädu, ktorí nemali vlastné studne. V Norimbergu bolo v 15. storočí až sto verejných studní (Siklósi 2003, 220). V stredovekom Székesfehervári boli vyhíbené na dvoroch siedmich domov, z toho boli štyri v pivniciach (Siklósi 2003, 228). V stredoeurópskych mestách je pomerne dobre spracovaná problematika studní a cisterien (Dohnal 1964; Vendtová 1966; Skružný 1995; Široký 2000, 348356; Nagy, Á. 2003; Sowina 2009, 148-235). 


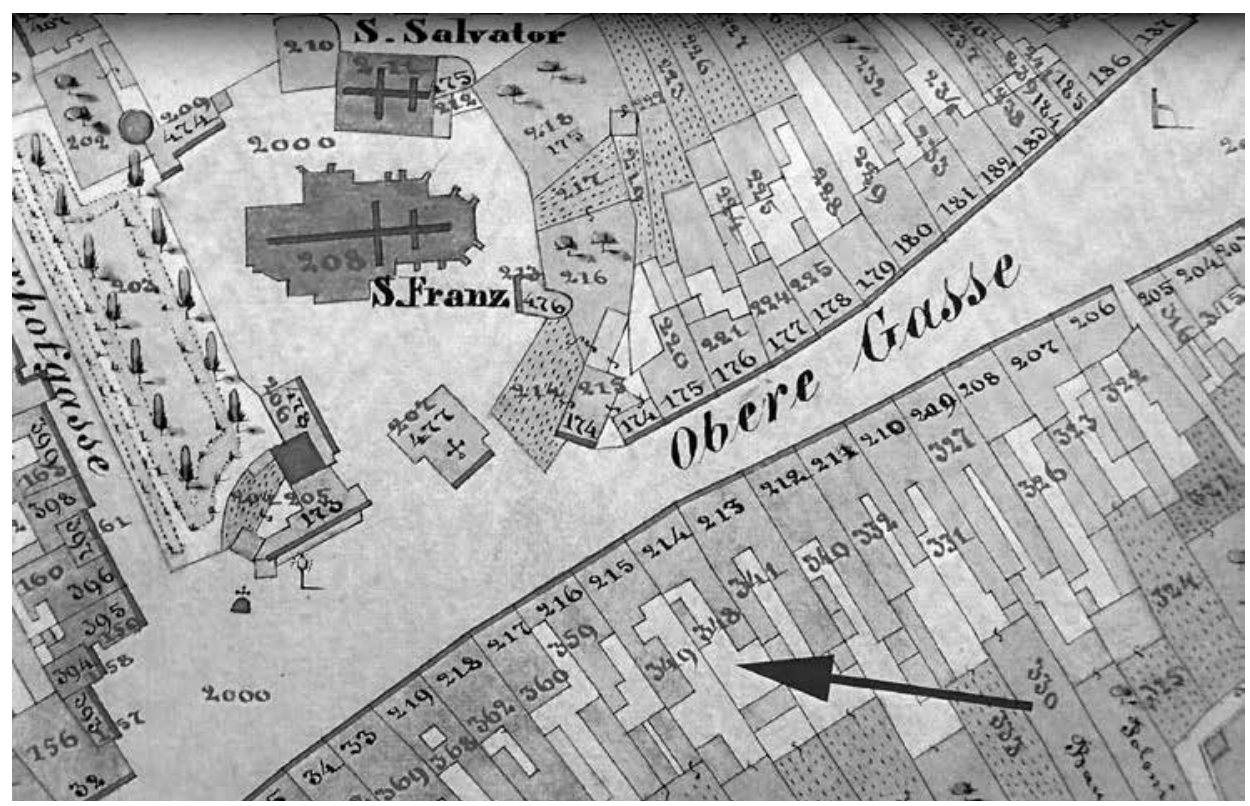

Obr. 2. Banská Bystrica, Horná ulica č. 2-4. Zameranie parciel so zakreslenou sondou I/08, v ktorej bola zistená studňa a kanalizácia. Podl'a Zachar 2008, výkres 05.

Abb. 2. Banská Bystrica, Obere Gasse Nr. 2-4. Parzellenvermessung mit eingezeichnetem Sondierschnitt I/08, in dem ein Brunnen und die Kanalisation entdeckt wurde. Nach Zachar 2008, Plan 05.

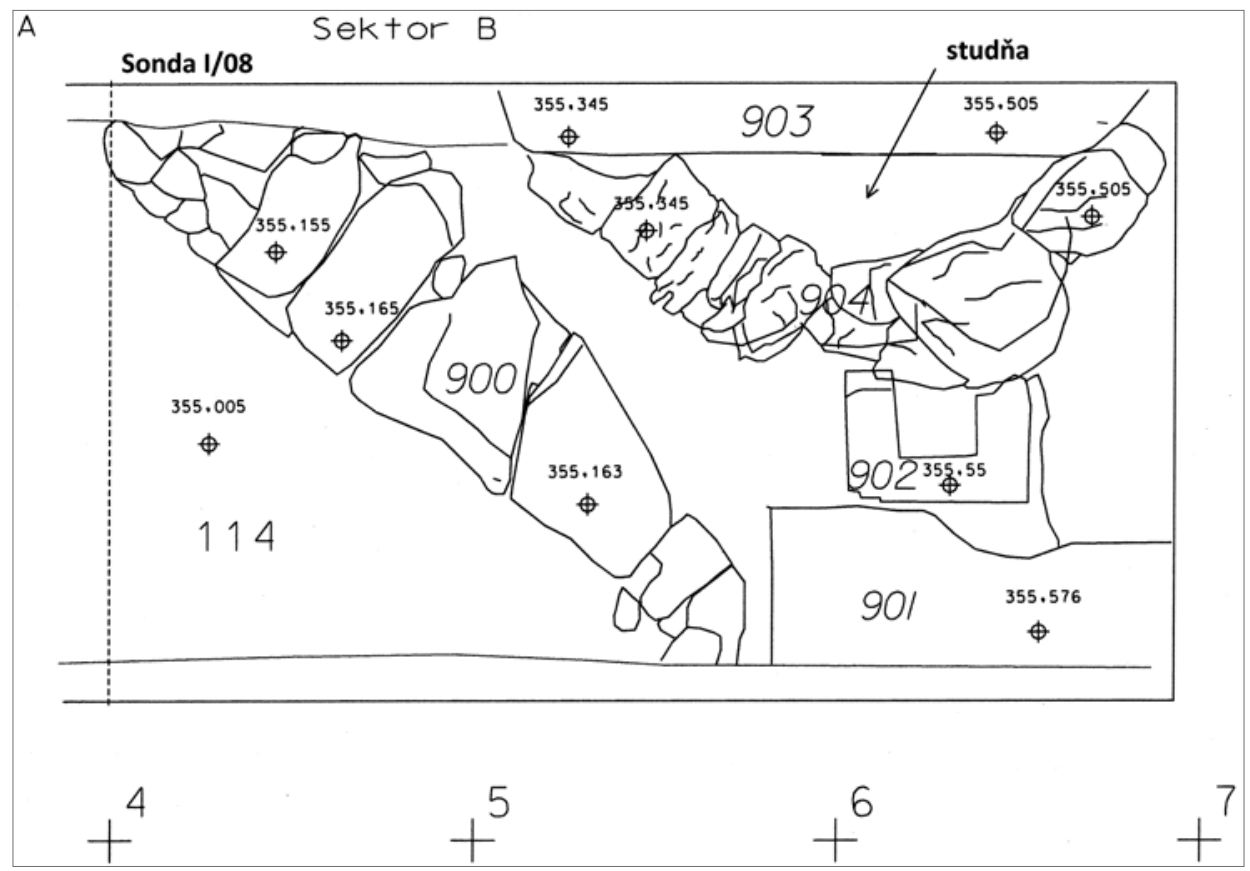

Obr. 3. Banská Bystrica, Horná ulica č. 2-4. Nálezová situácia v sonde I/08 s vyznačenou čast’ou studne a novodobého kanála. Podl’a Zachar 2008, výkres 08 .

Abb. 3. Banská Bystrica, Obere Gasse Nr. 2-4. Fundsituation in Sondierschnitt I/08 mit eingezeichnetem Brunnenteil und neuzeitlichem Kanal. Nach Zachar 2008, Plan 08. 
Banskobystrickým studniam sa doposial' venovalo málo priestoru. Stredoveké parcely v meste sú husto zastavané a počas prestavieb v dvorných traktoch sa v nich v minulosti neuskutočnil archeologický výskum. V písomných prameňoch sa dočítame o deviatich drevených zásobníkoch na vodu. V strede Hlavného námestia (dnešné Námestie SNP) dala mestská rada v roku 1633 postavit' kamenárom Tomášom Wolfom nádrž s mosadznou sochou za pomerne

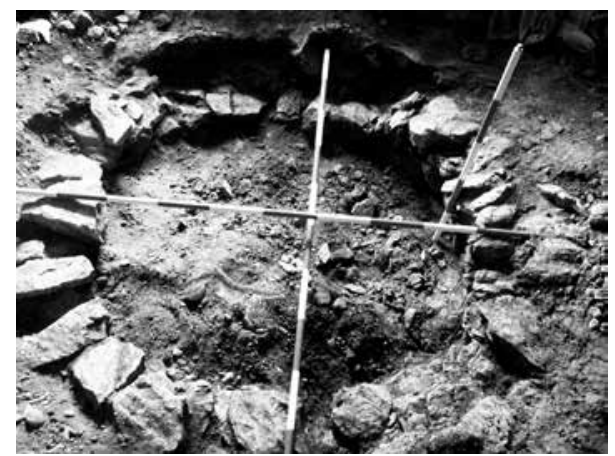

Obr. 4. Banská Bystrica, Námestie SNP č. 1 - radnica. Dvorný trakt bývalého meštianskeho domu. Kamenná studňa kruhového priemeru z lomového kameňa. Výskum M. Miňu v roku 2008. Foto M. Miňo.

Abb. 4. Banská Bystrica, Platz des Slowakischen Nationalaufstandes Nr. 1 - Rathaus. Hoftrakt eines ehemaligen Bürgerhauses. Runder Steinbrunnen aus Bruchsteinen. Grabung von M. Miňo aus dem Jahr 2008. Foto M. Miňo.

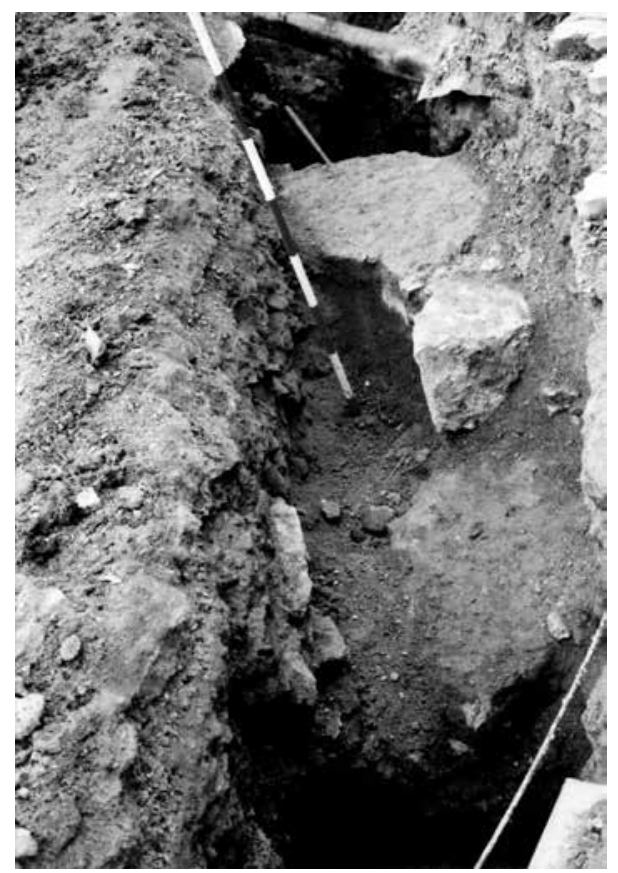

Obr. 5. Banská Bystrica, Námestie SNP č. 4 - dvorný trakt. Studňa z kamenných tesaných kvádrov spájaných maltou. Foto M. Mácelová.

Abb. 5. Banská Bystrica, Platz des Slowakischen Nationalaufstandes Nr. 4 - Hoftrakt. Brunnen aus mit Mörtel verbundenen, gehauenen Steinquadern. Foto M. Mácelová. vysokú odmenu 500 zlatých (Jurkovič 2005, 478). A. Filip $(1938,58)$ uvádza, že v roku 1563 bola jedna kašna na mestskom hrade a druhá pred ním ,Wasserkasten vor Brücke zur Burg“" a studňa s jednoduchým čerpadlom $\mathrm{v}$ hornej časti námestia.

Z nálezov studní, ktoré sú archeologicky doložené, spomenieme jednu zistenú na Hornej ulici 2 (obr. 2 a 3; Zachar 2008, 10, obr. 20; 2009, 287), druhú v južnej časti tej istej parcely, ktorú v súčasnom období skúma M. Kvietok a d'alšiu studňu čiastočne odkrytú M. Miňom v roku 2008 v dvornom trakte meštianskeho domu na Námestí SNP č. 1 v budove súčasnej radnice (obr. 4; Miňo-BrezňanováFratričová 2008). V roku 2003, počas opravy havárie kanalizácie $\mathrm{v}$ dvornom trakte domu na Námestí SNP č. 4 bol čiastočne porušený veniec studne, vyhotovenej z kamenných tesaných kvádrov spájaných maltou s priemerom 120 cm (obr. 5; Mácelová 2004, 134, obr. 91:1). Vo výkopovej ryhe sa našla stredoveká i novoveká keramika z 15.-18. storočia. Z poverenia mestskej rady Banskej Bystrice vypracoval miestny lekár L. Rajtsits (1896) v roku 1896 správu o Zdravotníctve slobodného královského mesta Banská Bystrica s osobitým zretel'om na asanačné práce poslednej dekády, ktorú monograficky vydal. Jej súčast’ou je mapa námestia s pril'ahlými ulicami a domami, na ktorej sú zakreslené všetky studne, v ktorých sa v roku 1895 zistovala čistota vody. Prázdnymi krúžkami sú zaznačené staré vodovodné studne (obr. 6).

\section{Vodovody}

Obyvatel'stvo $\mathrm{v}$ mestách produkovalo vel'ké množstvo odpadu, ktorý sa hromadil na smetiskách, čo malo za následok vznik rôznych infekcií. Už v 13. storočí boli prijaté nariadenia na udržiavanie čistoty vôd a likvidáciu odpadu (Goetz 2005, 338-339). Z dôvodov pretrvávajúceho problému znečist'ovania riek a potokov splaškami a odpadkami sa mestské rady začali zaoberat' problémom budovania mestských vodovodov po vzore kláštorných 


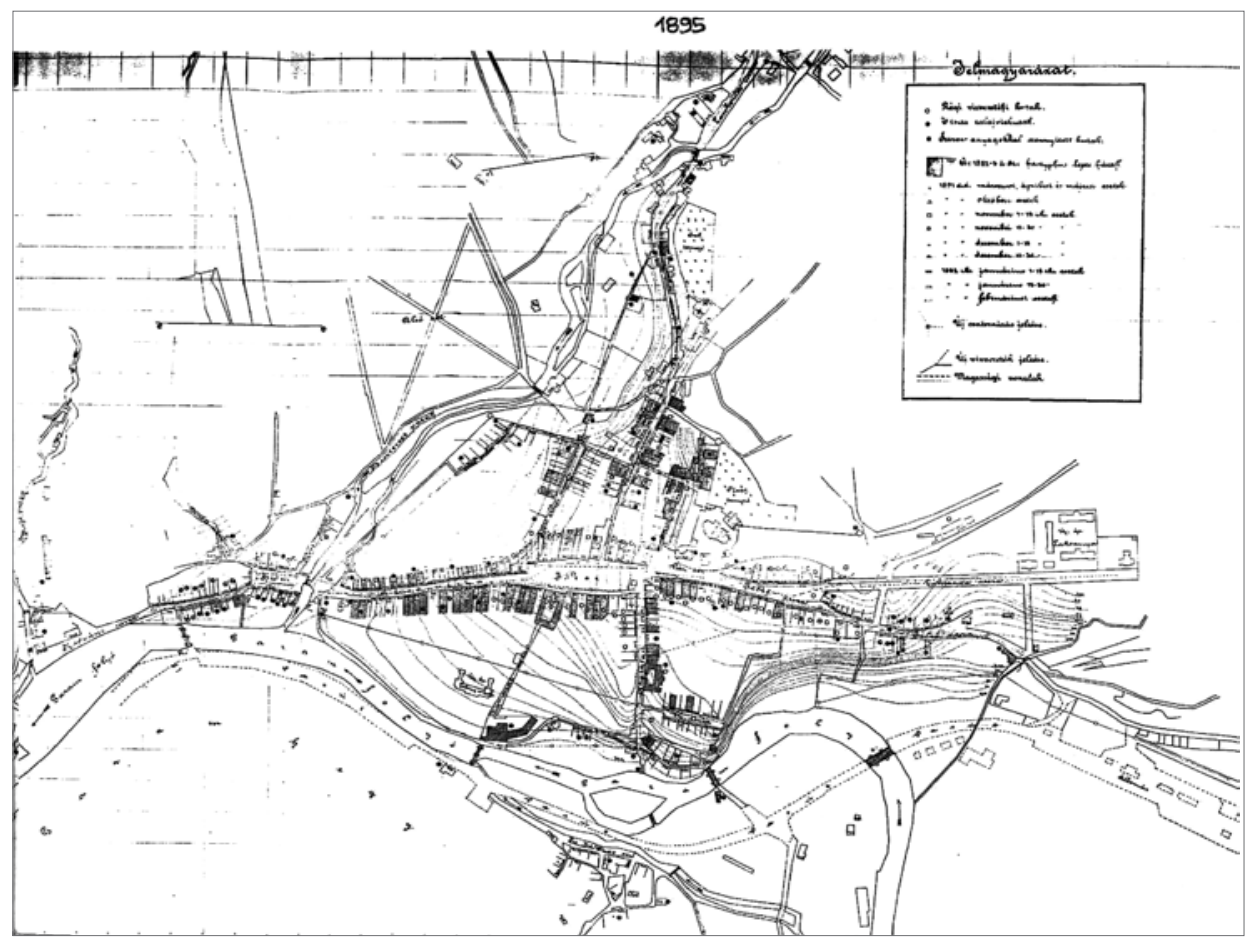

Obr. 6. Banská Bystrica. Plán mesta z roku 1895 so zakreslenými starými studňami označenými prázdnymi krúžkami. Plné krúžky označujú vodu kontaminovanú chemickými látkami. Podl’a Raitsits 1896.

Abb. 6. Banská Bystrica. Stadtplan von 1895 mit eingezeichneten und leeren Kreisen gekennzeichneten alten Brunnen. Die vollen Kreise kennzeichnen mit chemischen Stoffen kontaminiertes Wasser. Nach Raitsits 1896.

vodovodných zariadení (Habovštiak 1971; 1997). Naliehavou otázkou existencie obyvatel’ov stredovekých miest sa stalo zásobovanie pitnou vodou. Problematiku zásobovania miest pitnou vodou v stredovekých mestách strednej Európy riešia početné domáce i zahraničné štúdie (Huml 1975; Hanušin 1986; Grewe 1986; Jordánková-Sulitková 1991; Široký 2000; Nagy, Á. 2003; Siklósi 2003; Nagy, P.-Čurný 2011). Okrajovo sa jej venoval aj M. Slivka (1986). Najnovšie komplexne spracovala túto otázku pol'ská bádatel'ka Urszula Sowina v monografii Voda a l'udia (2009).

Stavby vodovodných zariadení patria k výrazným technickým výdobytkom stredovekých miest. Bol to fenomén a súčast' stavebnej kultúry stredovekého mesta. Napriek nepočetným písomným zmienkam o vodovodnom zariadení v Banskej Bystrici, ktoré sa spája s fortifikačnými prácami v mestskom hrade v 15 . storočí, doposial' chýbali hmotné doklady o jeho existencii. Až intenzívny archeologický výskum v mestskom jadre $v 90$. rokoch 20. storočia priniesol prekvapivé výsledky a doklady o súčastiach dreveného vodovodu a o odvádzačoch odpadovej vody, ktoré chceme prezentovat' $\mathrm{v}$ našom príspevku.

Rýchlo sa rozvíjajúce banské mesto, vd’aka rudnému bohatstvu v Starohorských vrchoch, patrilo $\mathrm{k}$ jednému z mála slovenských miest, v ktorom už v 15 . storočí existoval vodovod. Rovnako ako v Bardejove (Hanušin 1986, 245), aj v Banskej Bystrici môžeme nájst' v účtovnej knihe zápis o lámaní kameňa pre obloženie priekopy z roku 1480 (Lichner 1964, 1). V mestskej knihe z roku 1482 sa uvádzajú práce na prívodných rúrach „,arbatten dy Rorn haben aufgehebt“, ktoré boli vyrábané z dreva (Filip 1938, 58, pozn. 51). Práce na výstavbe vodnej priekopy viedol Maister Hannsen (Graus 2000, 7). Hradobné múry sa dvíhali z dna priekopy a tvorili jej vnútornú stenu (Fillová-Mácelová-Šimkovič 2002, 356-357). Voda sa do zámockej priekopy privádzala 
od prameňa spod Panského dielu (1 104 m n.m.) vodným kanálom cez Sásovskú dolinu, Sásovú (410 m n.m.), po úpätí vrchu Stráža a Jasenskom víšku. Dokladom je aj názov v bývalom sásovskom chotári „Nad rybníkom“ (Pisoň a kol. 1968, 168), ktorý mohol plnit’ funkciu vodnej nádrže. Podl'a U. Sowiny $(2009,306)$ sa pri stavbe vodovodov budovali rybníky a nádrže, do ktorých sa rúry máčali pred ich uložením do zeme. Zaručovalo to lepšiu priliehavost'.

$\mathrm{O}$ vodnej priekope hovorí aj listina z roku 1524, ktorou sa mestská rada Banskej Bystrice obrátila na L'udovíta II. s požiadavkou na vystavenie nového privilégia. V bode 14 sa píše o „povinnosti každého poddaného doviest' ročne na zámok 3 fúry dreva, čistit' zámockú priekopu a vykonávat' práce podla príkazov richtára a zámockého kapitána“ (Matulay 1980, 184, č. 569). Vodný kanál viedol v Banskej Bystrici cez mestské opevnenie rovnako ako v Lübecku (Grewe 1986, 282). Hlavná nádrž vodovodu bola v areáli mestského hradu, odkial' sa rozvádzala do kúpel’a, do nádrží a budov a ulíc na námestí (Ratkoš 1964, 244). Na rekonštrukcii plánu mesta z rokov 1525-1526 (Ratkoš 1964, 244, mapa 3) je v pravom hornom rohu zakreslený vodovod vedúci zo Sásovej do nádrže v areáli mestského hradu (obr. 7).

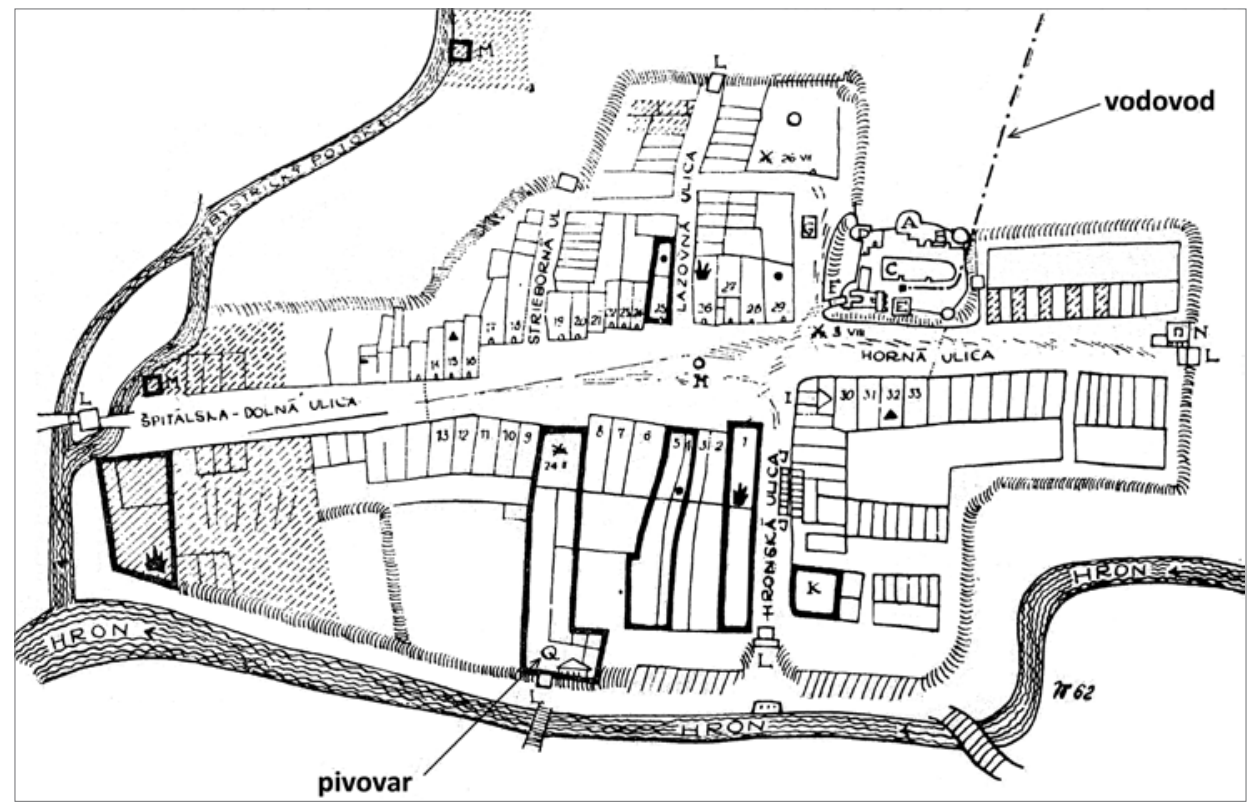

Obr. 7. Banská Bystrica. Kresebná rekonštrukcia plánu mesta z rokov 1525-1526. V pravom hornom rohu je vyznačená trasa vodovodu vedúceho zo Sásovej do mestského hradu, v strede v dolnej časti označený pivovar, nachádzajúci sa na parcele Komorského dvora. Podl'a Ratkoš 1964, 244, mapa 3.

Abb. 7. Banská Bystrica. Zeichenrekonstruktion des Stadtplans von 1525-1526. In der rechten oberen Ecke die aus der Siedlung Sásová in die Stadtburg führende Wasserleitungstrasse, im unteren Teil eine sich auf der Parzelle des Kammerhofs befindende Brauerei. Nach Ratkoš 1964, 244, Karte 3.

Na dobovej fotografii z rokov 1938-1939 je zachytený kamenný oblúk klenby vodného kanála v hradobnom múre (Baláž 2004, 96, obr. 113). Počas povstania baníkov v auguste 1526 baníci vodný kanál poškodili a vyrazili čapy z nádrže (Ratkoš 1957, 197, 241). V roku 1543 sa v mestskom hrade vybudovala studňa, ktorá nahradila dovtedajšiu cisternu a vykonali sa aj stavebné práce na vodnej priekope (Graus 2000, 8-9). Predpokladá sa, že zdroj zo sásovskej prívodnej vetvy bol zrejme bohatý a dostačujúci, nakol'ko vždy napíňal priekopu vodou po jej pravidelnom vypustení a vyčistení. Okrem sásovského kanála mesto vybudovalo aj kanál privádzajúci vodu z Kostiviarskej. Zápisy o ňom sú z rokov 1555, 1561 a 1583. Konštatuje sa v nich, že čistejšia voda bola zo sásovského privádzača (Ratkoš 1964a, 117, pozn. 49). Vodná priekopa sa ešte v roku 1531 odvodňovala prostredníctvom drevených žl’abov, stály odvodňovací kanál sa 
vykopal a vymuroval až v roku 1536 (Graus 2000, 7, pozn. 38). Na najstaršej zachovanej mape Banskej Bystrice z roku 1786 je zaznačený pozostatok bývalej vodnej priekopy, zasypanej po požiari historického jadra v auguste 1761 (obr. 8; Baláž 2004, 22, obr. 22).

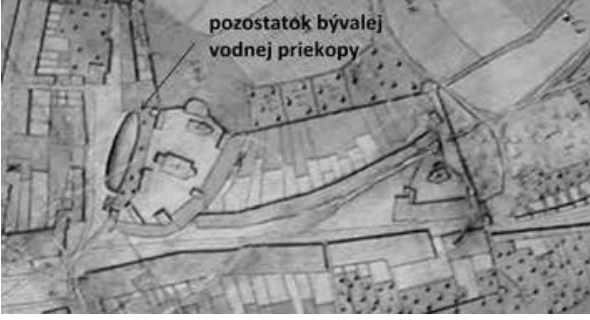

Obr. 8. Banská Bystrica, mestský hrad. Výrez mapy z roku 1786 so zakresleným pozostatkom vodnej priekopy. Podl’a Baláž 2004, 32, obr. 22.

Abb. 8. Banská Bystrica, Stadtburg. Ausschnitt aus einer Karte von 1786 mit eingezeichnetem Überrest des Wassergrabens. Nach Baláž 2004, 32, Abb. 22.

Mestský archivár A. Filip (1936, 58) píše, že zmienky o vodovode (Wasserkunst, alebo Kunst) sú v každej zachovanej bystrickej mestskej knihe, tie ale nie sú spracované. $\mathrm{V}$ našom príspevku sa opierame o doposial' neprekonanú historickú monografiu o dejinách Banskej Bystrice od Emila Jurkoviča, ktorý pôsobil ako profesor klasických jazykov na tunajšom královskom katolíckom gymnáziu. Monografia, ktorá v slovenskom preklade historika I. Nagya vyšla po 83 rokoch od jej vzniku, bola napísaná v mad’arčine (Jurkovič 2005, 7-8). Jurkovičova práca, opierajúca sa o štúdium archívnych dokumentov priniesla pomerne vel'a materiálu o banskobystrickom vodovode. Píše sa v nej, že mesto nemá priaznivé pôdne pomery, preto bolo nútené pristúpit' k jeho výstavbe. Najstarším vodovodom bol gravitačný sásovský akvadukt, ktorý bol už v roku 1506 rekonštruovaný. V účtovnej knihe je zaznamená položka za vodu zo Sásovej v sume 32 zlatých 40 denárov a už v roku 1521 sa na tento akvadukt vynakladá 55 denárov „,na vylepšenie jám na hnanie vody" (Jurkovič 2005, 477, pozn. 156).

\section{Stredoveký vodovod z 15. storočia v dvorovom trakte na Námestí SNP č. 3}

Čast' dreveného vydlabaného koryta tohto vodovodu sa našla počas archeologického výskumu v roku 1995 v dvorovom trakte na Námestí SNP č. 3, na parcele č. 1455/1 (obr. 9; Mácelová 1997, 129). V sonde I/95 sa zistil stredoveký objekt z 15. storočia, ktorý zhorel pri požiari mesta 10. apríla 1500 a novoveké architektúry zo 16.-17. storočia (obr. 10; Mácelová 1996, 425), datované fragmentom uhorského denára z obdobia 1559-1620 (Mácelová 1998, 112). V híbke $70-80 \mathrm{~cm}$ bola stredná plocha sondy vydláždená súvislou vrstvou okruhliakov. Pod ňou sa na-

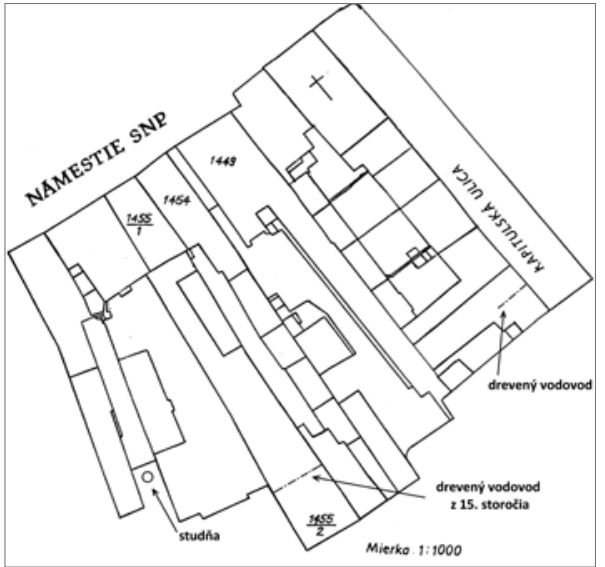

Obr. 9. Situačný plán domov č. 1-5 na Námestí SNP so stredovekým vodovodom a studňou. Kresba D. Tatar.

Abb. 9. Lageplan der Häuser Nr. 1-5 auf dem Platz des Slowakischen Nationalaufstandes mit mittelalterlichen Wasserleitung und Brunnen. Zeichnung D. Tatar. šla dobre zachovaná drevená doska $\mathrm{z}$ duba (Quercus sp.) široká $35 \mathrm{~cm}$, ktorá zakrývala drevené vodovodné potrubie. Potrubie bolo vydlabané z troch štvrtín obvodu kmeňa jedle bielej, okolo $50 \mathrm{~cm}$ hrubého (Abies alba; Hajnalová-Mihályiová 1998, 61). Cievy vzorky potrubia z jedle bielej boli vyplnené organickou hmotou svetlej farby, ktorá slúžila na konzervovanie dreva proti priesakom (Hajnalová-Mihályiová 1996, 11). Drevené potrubie bolo zabezpečené priečnymi a pozdížnymi doskami proti posunu a okolie bolo vydrenážované riečnymi okruhliakmi (obr. 11). Pokračovanie vodovodu sa zistilo aj v najzápadnejšej časti parcely, ale sonda vytýčená na susednej parcele č. 1454 na Námestí SNP č. 2 nepotvrdila pokračovanie dreveného potrubia $\mathrm{z}$ dôvodu porušenia terénu novodobou kanalizáciou z 20. storočia, uloženou v híbke $180 \mathrm{~cm}$. Vydlabané koryto časovo bližšie 


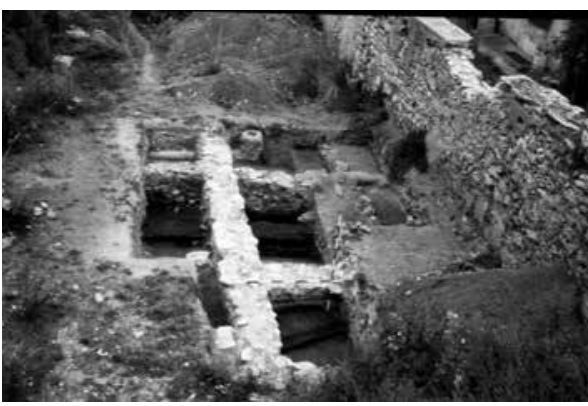

Obr. 10. Banská Bystrica, Námestie SNP č. 3. Sonda I/95 s renesančnými základmi architektúry zo 16.-17. storočia, dreveným vodovodom a dreveným odtokovým žl'abom z 15. storočia. Foto M. Mácelová.

Abb. 10. Banská Bystrica, Platz des Slowakischen Nationalaufstandes Nr. 3. Sondierschnitt I/95 mit renaissancezeitlichen Fundamenten einer Architektur aus dem 16.-17. Jhdt., einer hölzernen Wasserleitung und einer hölzernen Abflussrinne aus dem 15. Jhdt. Foto M. Mácelová.

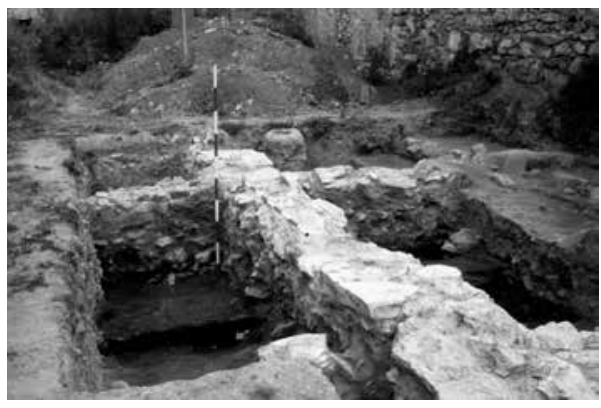

Obr. 11. Banská Bystrica, Námestie SNP č. 3. Drevený vodovod z 15. storočia a renesančné základy zo 16.-17. storočia. Foto M.Mácelová.

Abb. 11. Banská Bystrica, Platz des Slowakischen Nationalaufstandes Nr. 3. Hölzerne Wasserleitung aus dem 15. Jhdt. und renaissancezeitliche Fundamente aus dem 16.-17. Jhdt. Foto M. Mácelová.

neurčené, prekryté doskou, privádzalo vodu do studní aj v Uherskom Brode (Pavelčík 1955, 146-147). Prvý v Nemecku detailne opísaný drevený vodovod je zo Stralsundu. Na jeho výrobu boli použité kmene stromov z jedle a borovice (Grewe 1986, 289). Drevené potrubia vydlabané z kmeňov považuje Grewe $(1986,285)$ za starší typ, za novší považuje vodovod z vítaných drevených rúr $(1986,286)$. Aj tento typ potrubia sa zistil v juhozápadnej časti sondy. Drevená rúra bola spojená železnou obručou so zosilneným stredovým rebrom (Röhrenfahrt; Grewe 1986, 285). Podobne boli spojované drevené rúry aj v Prahe na Václavskom námestí (Huml 1975, 224, 230, obr. 4:1), v Kroměříži (Chybová 2009, obr. na s. 312) a v iných stredoeurópskych mestách.

Grewe $(1986,292)$ sa zaoberal aj technológiou dlabania kmeňov (Piepen) pomocou vrtákov, obrázok znázorňujúci vítanie rúr pre banské pumpy je súčast’ou kolorovanej monografie G. Agricolu (1557) Dvanást' kníh o baníctve (obr. 12). Výrobou a vítaním vodovodných rúr sa zaoberajú štúdie V. Humla (1975, 226-229), R. Širokého $(2000,336,367)$ i monografia U. Sowiny (2009, 301-309). Rúry sa vŕtali pomocou nebožieca so slimákovým závitom (Huml 1975, 226; Grewe 1986, 286, obr. 14, 16). Vyvŕtané otvory bolo nutné vypálit' žeravým železom proti prienikom vody do dreva, aby toto nezačalo hnit' a rozkladat' sa (Chybová 2009, 312). Drevené rúry sa vkladali do vrstvy ílu, ktorý bránil nežiaducim únikom, tiež do izolačnej vrstvy riečneho piesku. V Kroměřiži boli podkladané drevenými podložkami a proti pohybu vrazenými kolmi z každej strany. Na čistenie vnútrajška potrubia boli niektoré rúry opatrené kónusovým otvorom, ktorý sa zatváral zátkou (Chybová 2009, 311, obr. na s. 312).

Zaujímavé výsledky priniesli analýzy vzoriek zeminy z výplne pravdepodobne najstaršieho doposial' zisteného banskobystrického vodovodu z kmeňa jedle bielej. Po preplavení vzoriek z odobraných 37 litrov zeminy zo šiestich polôh v potrubí a jeho okolí sa zistilo 2800 semien ( 80 botanických taxónov) a iných organických nálezov. Výrazné zastúpenie majú nezuhol’natené semená a zvyšky plodov z ovocia, pochádzajúce z vegetácie stredovekej záhrady, ktoré sa dostali do deštruovaného potrubia v priebehu dvadsiatich rokov od jeho vloženia do zeme (HajnalováMihályiová 1995; 1998, 62). Názory na životnost' drevených vodovodov nie sú u jednotlivých bádatel'ov jednotné, záviseli zrejme od miestnych podmienok (Široký 2000, 366). Až pät’desiatročnú životnost' dreveného potrubia predpokladá V. Huml (1975, 223).

V južnej časti sondy sme v híbke $60-65 \mathrm{~cm}$ zistili aj plochý, $23 \mathrm{~cm}$ široký odtokový žlab, ktorý nebol rovnobežný s vodovodom a slúžil na odvádzanie vody z parcely (obr. 13). V juhozápadnej časti sa našiel $30 \mathrm{~cm}$ dlhý kus olovenej zlomenej trubky, pravdepodobne z mladšieho vodovodu. Najstarší zistený drevený vodovod prechádzal záhradou stredovekého meštianskeho domu, ktorý patril thurzovskému faktorovi Jánovi Meczlerovi. Tento bol zatom banského t’ažiara Jána Thurzu (Matulay 1980, č. 324 a 432). 


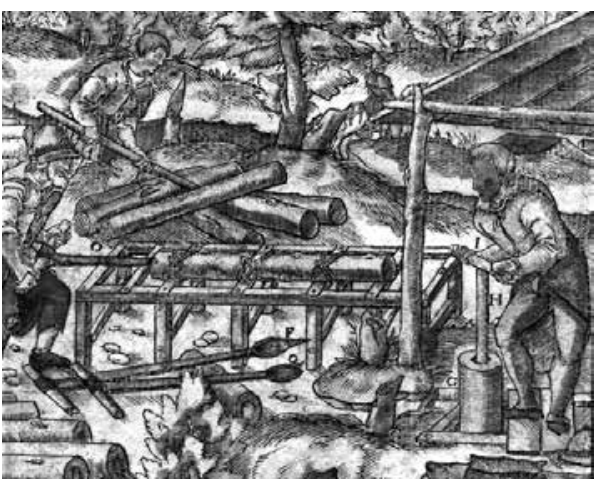

Obr. 12. Vŕtanie rúr pre banské pumpy. Podl’a Agricola 1557. Abb. 12. Arbeiter beim Röhrenbohren für Grubenpumpen. Nach Agricola 1557.

\section{Novoveký vodovod na Námestí Š. Moysesa}

Počas sledovania výmeny inžinierskych sietí na Moysesovom námestí (bývalé Horné námestie) v máji až septembri 1996 sa v híbke $120 \mathrm{~cm}$ zistil stredoveký vodovod vyhotovený z drevených prevítaných brvien, ktoré mali hrúbku okolo $27-30 \mathrm{~cm}$ a boli spájané železnými obručami so zosilneným stredovým rebrom (Mácelová-Mosný 1998, 115, obr. 60:4, 5). Priemer otvorov v potrubí bol od 7 do $10 \mathrm{~cm}$. Systém vodorovných a kolmých rúr tvoril vodovodnú siet', ktorá privádzala vodu z Kostiviarskej, do domov na námestí a pril’ahlých ulíc. V marci 1997 počas híbenia rýh pre nové inžinierske siete na pravej strane hlavnej cesty na Námestí Š. Moysesa porušili stavebné mechanizmy vodovodné potrubie, ktoré bolo položené do ílovitého lôžka v híbke $110 \mathrm{~cm}$. Drevené rúry boli fotograficky zdokumentované pred domami č. 5-8 (obr. 14). Dížka porušeného potrubia merala približne $3 \mathrm{~m}$ (obr. 15). Nepodarilo sa zdokumentovat' dížku jednotlivých poškodených rúr, ani zistit', akým spôsobom boli spájané. Pre rýchly postup prác sa neodobrali ani vzorky dreva, konštatujeme len, že kmene boli zbavené kôry.

Na výrobu vodovodných rúr v Banskej Bystrici sa používalo drevo z červeného smreka. Dozvedáme sa o tom z písomného konceptu z roku 1583, podl'a ktorého mestská rada pred komorskými komisármi požiadala o ochranu červeného smreka, ktorý nevyhnutne potrebovala na výrobu vodovodného potrubia (Jurkovič 2005,478 , pozn. 171). U. Sowina $(2009,302)$ uvádza, že v Krakove a v Lubline sa používalo sosnové drevo, rovnako tento druh uvádzajú v malopol'skom Krośnie A. Muzyczuk-J. Gancarski (2003, 33). Modrý smrek bol použitý v Nowom Sąnszi na konci 19. storočia, pričom nie je isté, či sa z neho vyrábalo potrubie aj v 16. storočí. U. Sowina (2009, 303, pozn. 906) cituje autora Albertiho $(1960,52)$, ktorý o červenom smreku napísal, že „má všetky prednosti, aby dlho vydržal, je silný, vláknitý, nepodlieha črvotoči a nepoškodí ho ani ohěn, nakol'ko črvotoč nepoškodzuje to drevo, ktoré je vo vnútri olejnaté, lepkavé a najmä trpké“. Potrubie z červeného smreka bolo použité pri stavbe zámockého vodovodu v rakúskom Grazi v rokoch 1494-1500.

V stredoslovenských banských mestách sa stretáme aj s vysokou konzumáciou piva, o čom svedčí aj pivovarnícke právo vzt’ahujúce sa na 32 domov na námestí v Banskej Bystrici, ktoré mali právo varit’ a čapovat' pivo (Petráš 1993, 9). K jeho výrobe bola potrebná čistá nezávadná voda, ktorá zaručovala vysokú kvalitu piva (Krajíc 1989, 181). Zvýšený dopyt po pive zrejme zapríčinila aj závadnost' povrchových zdrojov vody a aj nižšia cena oproti vínu. Najstaršia správa o banskobystrickom pivovarníctve pochádza z roku 1501, právo varit' jačmenné pivo mal každý občan mesta, existoval tu mestský pivovar a pivo varila aj thurzovsko-fuggerovská mediarska spoločnost' (Žilák 1993, 68). Najstarší známy bystrický pivovar pochádza z 15. storočia a nachádzal sa vo dvore Komorského domu na dnešnom Námestí SNP č. 8 (obr. 7). 


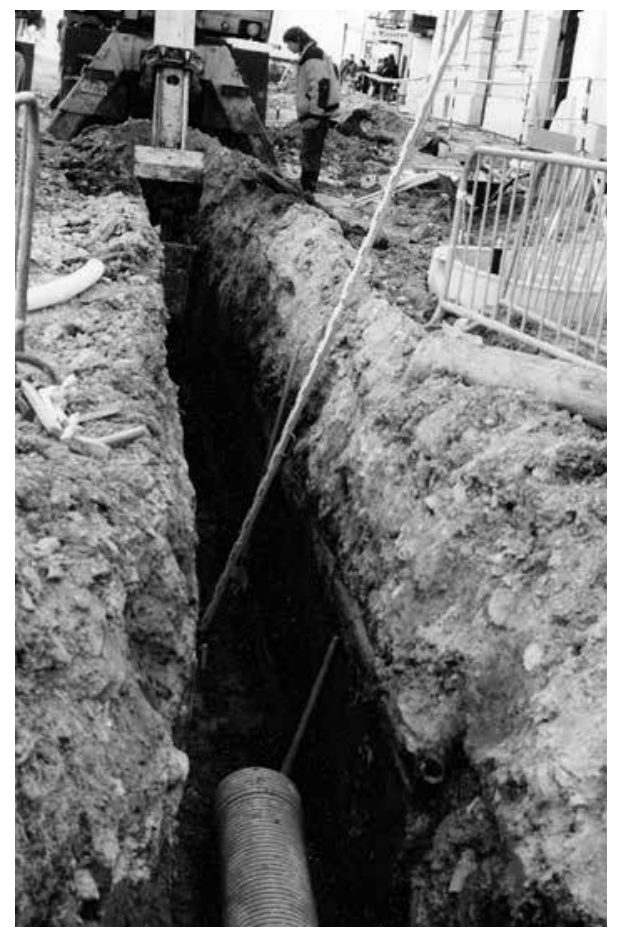

Obr. 14. Banská Bystrica. Námestie Š. Moysesa č. 5-8. Porušené drevené potrubie vodovodu $\mathrm{z}$ prevítaných rúr. Foto M. Mácelová.

Abb. 14. Banská Bystrica. Štefan-Moyses-Platz Nr. 5-8. Beschädigte, aus durchbohrten Röhren bestehende hölzerne Wasserleitung. Foto M. Mácelová.

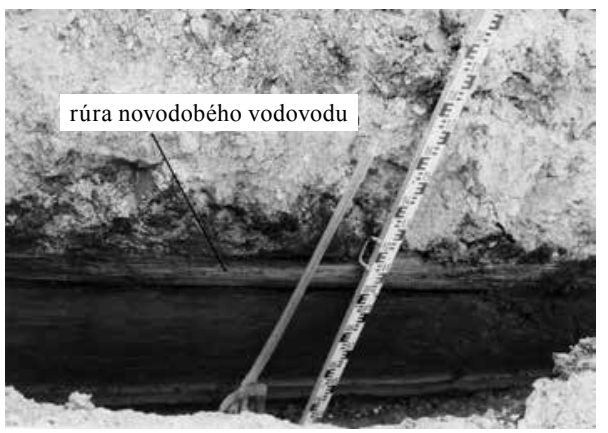

Obr. 15. Banská Bystrica. Námestie Š. Moysesa. Detail poškodeného dreveného vodovodu. Foto M. Mácelová.

Abb. 15. Banská Bystrica. Štefan-Moyses-Platz. Detail der beschädigten hölzernen Wassleitung. Foto M. Mácelová.
Predpokladáme, že drevené koryto vodovodu zistené $\mathrm{v}$ dvorovom trakte na Námestí SNP č. 3 mohlo privádzat' vodu práve do tohto pivovaru. Jednotliví meštania sa po dosiahnutí výsady varenia piva (Wasserrecht) usilovali o zavedenie vodovodnej prípojky na svoj pozemok. Zamietavé stanovisko mestskej rady pre Ondreja Kreusela (ŠA MBB, Protocol praetorii z roku 1543-1550) hovorí o opatrnosti pri vydávaní rozhodnutia z obáv vysokej spotreby vody (Jurkovič 2005, 477, pozn. 160). V roku 1536 sa so žiadost'ou o zavedenie vodovodu obrátili na mestskú radu aj obyvatelia Hronskej, dnešnej Kapitulskej ulice (Jurkovič 2005 , 477). V 80. rokoch 20 . storočia počas prípravy staveniska pre Dom priemyselného tovaru na tejto ulici sme zistili časti vŕtaných rúr dreveného potrubia (nepublikované). V roku 1555 riešilo mesto žiadost' obyvatel'ov o zavedenie vodovodu do d'alších dvoch ulíc, Lazovnej a Striebornej (Jurkovič 2005, 477). Predpokladáme, že množstvo vody zo sásovského vodovodu už nepostačovalo vykryt' požiadavky čo do množstva dodávanej vody, preto sa o vybudovanie novej vetvy vodovodu zasadil sám vtedajší richtár Krištof Schwab, ktorý po porade s mestskou radou a obyvatel'mi Bystrice schválil stavbu novej sústavy na trase medzi Sásovou a Kostiviarskou (Jurkovič 2005, 477). Tento projekt opisuje spomínaný richtár v účtovnej knihe z roku 1555: „Pre už spomínaný vodovod a aj aby sa dnu do mesta voda priviedla, bude treba skaly lámat, piesok a kamene vozit', murárov, majstrov, nádenníkov, pracovníkov, drvičov skál, tesárov, odpal'ovačov a spolu všetko príslušenstvo, pohotovost' a potreby od 7. septembra až do 21. decembra vyplatit,' ako nasleduje." Bystrickí radní sa obrátili na odborníka Krištofa Abertshausera, ktorého zamestnával aj král'ovský dvor, aby riadil výstavbu vodovodu. Túto skutočnost' dokladá list K. Abertshausera z 5. decembra 1561, ktorý svoj krátky pobyt pri stavbe bystrického vodovodu odôvodnil nutnostou dozerat' na viaceré vodné stavby objednané král'ovským dvorom (Jurkovič 2005, 477, pozn. 158). Mesto za vybudovanie vodovodu zaplatilo 990 zlatých 42 denárov. V roku 1575 banská komora požiadala o zvýšenie prietoku vody pre pivovar, ktorý prevádzkovala v Komorskom dome. Ked' mestská rada nevyhovela tejto požiadavke, komora dala urobit' prípojku z ned’alekého Hronského vrchu (Urpína) s vodou vynikajúcej kvality (Jurkovič 2005, 477). Dopyt po pitnej vode rástol, aby bola vykrytá spotreba, v roku 1558 napojili na hlavný vodovod pramene z Vlčej doliny (Wolfsgrund), pričom náklady dosiahli čiastku 92 zlatých 611/2 denárov (Jurkovič 2005, 477, pozn. 159). V roku 1582 robil na 
drevenom vodovode opravy Krištof Kraňsky, ktorý ho vložil do kamenného kanálu, za čo dostal odmenu 16 zlatých. A. Filip $(1938,58)$ bližšie nešpecifikuje, na ktorom mieste sa robili opravy. Do konca 16. storočia boli vodovodné prípojky zavedené do všetkých mestských ulíc.

O sústave vetiev gravitačných vodovodov z Kostiviarskej a Sásovej nás informuje plán vodovodného potrubia z roku 1829 (ŠA MBB, Mp-35j). Na mape sú zakreslené aj plánované nové drevené vodovodné prípojky do jednotlivých domov na hlavnom námestí o dížke 137 siah (obr. 16). Jedna vetva vedie popri kostiviarskom mlyne zo Zelenej doliny, druhá popod Sásovú z Močiara do mesta, ku ktorej sa pripojila tretia, z Rudlovej. V legende sa uvádza, že dížka kanálov má byt' 2517 siah, otvorených potrubí 1631 siah, vol'ných jarkov na tečúcu vodu od prameňov 3639 siah a vel'kých rúr 137 siah. Celková dížka potrubia má dosiahnut' 7924 siah.

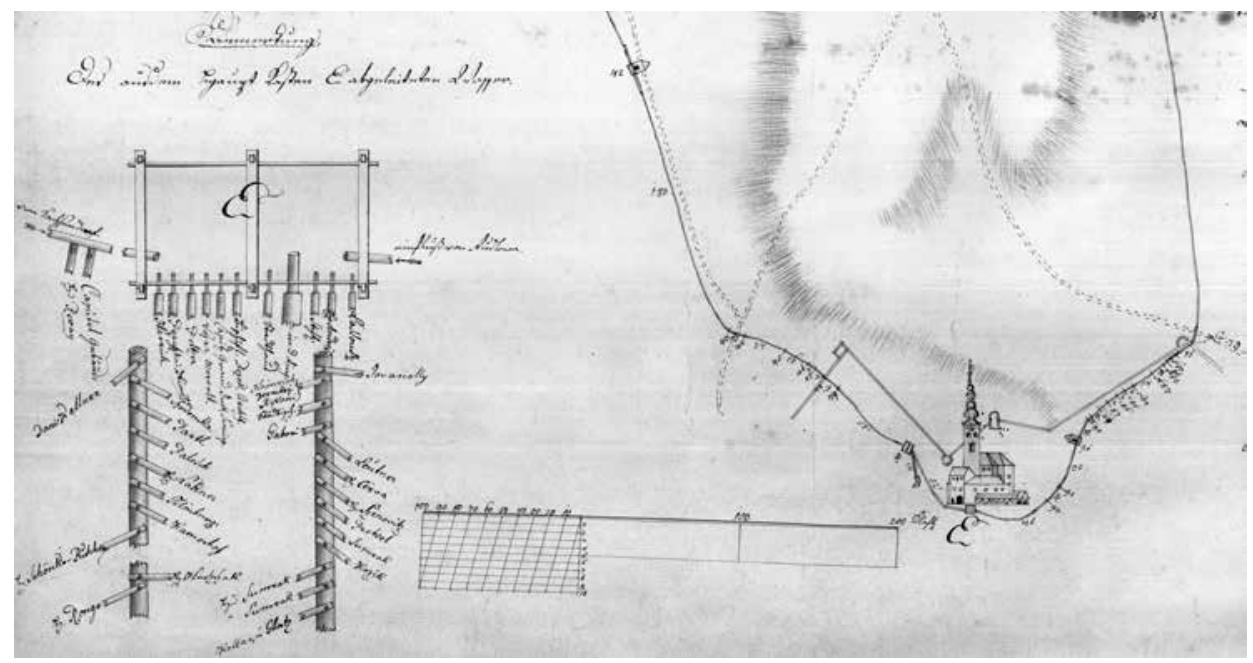

Obr. 16. Banská Bystrica. Výrez plánu vetiev vodovodu z Kostiviarskej a Sásovej s prípojkami do domov na námestí z roku 1829. Štátny archív v Banskej Bystrici, fond MBB, Mp-35j.

Abb. 16. Banská Bystrica. Planausschnitt der aus den Siedlungen Kostiviarská und Sásová geführten Wasserleitungsstränge mit Anschlüssen für die am Marktplatz liegenden Häuser aus dem Jahr 1829. Staatsarchiv in Banská Bystrica, Bestand der Stadt Banská Bystrica, Mp-35j.

Podzemný vodovod je zakreslený aj na katastrálnej mape Kostiviarskej z roku 1882 (obr. 17; ŠA MBB, Mp-87a).

Sásovský vodovod dlhý 1700 siah bol koncom 16. storočia na mnohých miestach poškodený, jednotlivé rúry sa prepadali a odstraňovanie potrubia si vyžadovalo značné financie. Na jeho opravu bolo potrebných 600-700 zlatých, preto sa mesto v roku 1575 obrátilo na arcivojvodu Ernesta o pomoc s odôvodnením, že komorské budovy neprispievajú na údržbu vodovodu, hoci spotrebúvajú takmer tretinu celomestskej spotreby vody (Jurkovič 2005, 478). Až v roku 1583 sa mesto dočkalo 200 zlatých na privedenie vodovodu z Rudlovej (Protocol praetoriale z 2. júla 1583). V účtovnej knihe z roku 1592 sa píše o „,zaplatení 20 zlatých Lackovi Rusnákovi za vykopanie a vymurovanie vodovodu za Obuvnickou baštou pomimo Obergesslerovej záhrady a následné pokrytie širokými kameňmi“" (Jurkovič 2005, 478, pozn. 165). Napriek tomu, že na udržiavanie potrubia boli vydané prísne štatúty už v 15. storočí a tieto boli každoročne zverejňované, dochádzalo $\mathrm{k}$ ich porušovaniu. V Protocole praetoriale z roku 1716 sa píše o znečistovaní vody Sásovčanmi, ktorí ju používajú na pranie šiat, čím sa voda stáva odpudzujúcou. Na udržiavanie potrubia bol poverený mestský tesár (Kunstmaister, städtische Zimmermaister, Wasserman, aquilex, Fontium magister), ktorý mal ročný plat 40 zlatých a služobný byt vo Farskej ulici, ktorý je vyznačený pod č. 42 na obr. 16 (v strede v hornej časti). Bystrický Kunstmaister bol zaviazaný dozorom nad zavádzaním vody do domov, inú prácu nemohol vykonávat' 


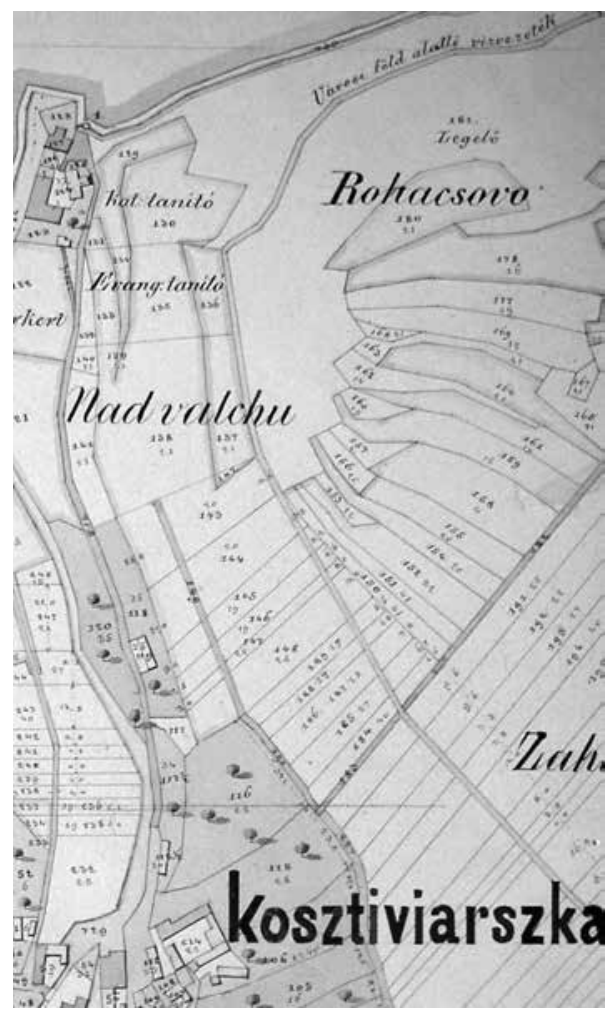

Obr. 17. Banská Bystrica, čast' Kostiviarska. Výrez katastrálnej mapy Kostiviarskej so zakresleným vodovodom $v$ pravom hornom rohu $z$ roku 1882. Štátny archív v Banskej Bystrici, fond MBB, Mp-87a.

Abb. 17. Banská Bystrica, Stadtteil Kostiviarska. Auschnitt einer Katasterkarte aus dem Jahr 1882 von der Siedlung Kostiviarská mit in der rechten oberen Ecke eingezeichneter Wasserleitung. Staatsarchiv in Banská Bystrica, Bestand der Stadt Banská Bystrica, Mp-87a.
(Protocol praetoriale 1727, 297). Z Bardejova poznáme prvého známeho rúrnika už z roku 1429. Bol ním Mikuláš z Krakova, v roku 1434 bol poverený $\mathrm{v}$ tomto meste vodnými prácami Michal Rormeister, tiež z Krakova (Hanušin 1986, 245, 247). Aj d’alší odborníci-rúrnici pochádzali z Krakova, kde pracovali na vodovodných prácach (Hanušin 1986, 248). Zaujímavostou je, že bardejovský drevený gravitačný vodovod bol funkčný až do roku 1954 (Hanušin 1986, 267). V Kežmarku mali vodovodného majstra v roku 1481. Drevený vodovod sa $\mathrm{v}$ písomných prameňoch spomína $\mathrm{v}$ roku 1495 a fungoval do roku 1912. Do mesta Kežmarok bola voda zavedená 10 . júna 1575 z predmestia Petra-Pavla. ${ }^{1}$ M. Domenová (2009, 64-65), ktorá sa okrajovo zaoberala aj vodami v Prešove, píše o novom akvadukte z roku 1527, ktorý privádzal vodu z Torysy, a tiež, že v Košiciach pri špitáli na Alžbetinej ulici sa spomína aquaduktor Peter. Vo svojej štúdii o bardejovskom vodovode sa J. Hanušin (1986, 248, 250) podrobne zaoberal aj vyberaním poplatkov za vodu, ktoré sa nazývali Röhrgeld (nemecky), census cannaru, canalista (latinsky), csatornapénz (mad’arsky), rúrne (slovensky).

\section{Odvádzanie odpadových vôd}

V stredoveku sa rovnaká pozornost', aká bola venovaná prívodu vody, venovala aj odvádzaniu odpadových vôd z parciel. Archeologický výskum v roku 1997 v mestskom hrade priniesol poznatky aj o stavbe múra, ktorého základy hlboké $3,4 \mathrm{~m}$ boli kolmé na hradbový múr. Mali šírku 0,65 m, dížku 7,8 m a boli z lomového kameňa, kladeného na silne vápennú, štrkovitú maltu rovnakou technikou ako hradbový múr, s ktorým ale neboli previazané. Predpokladáme, že boli postavené $\mathrm{v}$ rovnakom čase ako hradobný múr, $\mathrm{v} 80$. rokoch 15 . storočia, ktorý nahradil drevenú ohradu v mestskom hrade. Tesne pri týchto základoch boli v hradbovom múre zistené otvory, ktorými sa odvádzala spodná voda z vnútorného priestoru hradu (Mácelová 1999, 112). Múr plnil funkciu odtokového zariadenia, ktoré odvádzalo spodnú vodu z areálu. Napovedala by tomu aj zmienka E. Jurkoviča $(2005,478)$, že najstarší (nedatovaný) údaj hovorí o odkanalizovaní spodnej vody z krypty farského kostola do západnej časti hradnej priekopy.

Voda z mestského hradu bola odvádzaná odvodňovacím kanálom, na ktorý narazili robotníci počas pracovného víkendu 6. júla 1996 v híbke $250 \mathrm{~cm}$ na Moysesovom námestí pred domami č. 14 a 15 . Kanál bol zasypaný bez zdokumentovania a preskúmania. Podla výpovede mal murovaný zaklenbený kanál šírku asi $100 \mathrm{~cm}$ a výšku $120 \mathrm{~cm}$ (Mácelová 1998, 116, obr. 60:8). Jeho pokračovanie cez Krížnu ulicu zistil a zdokumentoval počas výskumu v októbri 2006 V.Hanuliak (2007, fotogr. tab. č. 8 a 14). Vzhl'adom na väčšie rozmery išlo zrejme o hlavný kanalizačný zberač.

1 Za informácie d'akujem kežmarskej historičke PhDr. Nore Barátovej, ktorá čerpala z monografie: Genersich, Ch., 1804: Merkwürdigkeiten der königlichen Freystadt Késmark, Kaschau-Leutschau I. 
Zmienku o kanalizácii, ktorú podl’a Protocolu praetoria z roku 1577 požadoval zasypat' kazatel' Gregor, by mohol potvrdit' nález kamenného odtokového kanála zisteného v sonde IX/96. Ten sa našiel západne od starej radnice, ktorá vyhorela pri požiari v roku 1500 (Mácelová 1998, 114). Pre udržiavanie kanalizácie slúžili opatrenia, týkajúce sa kontroly týchto zariadení, nad ktorými bdela komorská komisia a vydávala o nich zápisnice pod názvom Kontrola podzemných kanálov l'udovo označovaných Wasserseuch. Náklady za údržbu boli rozdelené medzi príslušných majitel'ov domov (Jurkovič 2005, 478, pozn. 178, 179).

Kanalizácia bola zistená na viacerých parcelách v dvorných traktoch na Námestí SNP č. 3, na Lazovnej ulici v sektore domov č. 12-14, kde sa našiel zvyšok novovekého kanálu tvoreného kamennými platňami, ktoré prekrývali paralelné kamenné stienky. Záklop kamenných platní bol kladený bez maltového spojiva. Pri spájaní vel'kých kamenných platní na Lazovnej ulici č. 21 bola ako spojivo použitá vápenná malta (Zachar-Mácelová 2007, 13). V Banskej Bystrici bol tento typ kanalizácie bežný od neskorého stredoveku po novovek (Zachar-Mácelová 2007, 14, obr. 27). Podobný novoveký odpadový kanál z konca 18. storočia sa zistil aj vo vnútri dvora na Hornej ulici 2 (Zachar 2009, 287). Jeho pokračovanie zistil počas tohoročného výskumu na tejto parcele M. Kvietok. S nálezmi stredovekej a novovekej kanalizácie sa bežne stretáme počas archeologických výskumov a prieskumov (Uličný 2000; Zachar 2009). P. Ušiak počas rekonštrukcie inžinierskych sietí na Námestí SNP v roku 1994 zistil a odobral z híbky $130 \mathrm{~cm}$ vzorku dreveného potrubia dlhú $74 \mathrm{~cm}$, ktoré pravdepodobne odvádzalo vodu z fontány. Bolo vyrobené z borovicového kmeňa s priemerom približne 20 cm (Ušiak 1996, 177, obr. 147). Na pláne mestskej štvrte medzi Hornou striebornou ulicou a Dolnou ulicou z roku 1851 sú zakreslené dva vodné kanály (Baláž 2004, obr. 192). Súčasný archeologický výskum M. Kvietka na Hornej ulici č. 2-4 odkryl aj pokračovanie kanalizácie zistenej J. Zacharom $(2009,287)$. Intenzívny výskum určite prinesie nové nálezy a zistenia $\mathrm{k}$ tejto problematike.

\section{Kamenný turčekovský vodovod}

Medzi významné vodné diela v banskom regióne stredného Slovenska je možné zaradit' aj technickú pamiatku kamenný turčekovský vodovod, ktorý dali postavit' Thurzovci koncom 15. storočia. V účtovnej knihe mesta Kremnica z roku 1464 sa spomínajú výdavky na turčiansky jarok (vodovod; Matunák 1928, 313). Jeho dížka je viac ako $15 \mathrm{~km}$ a privádzal vodu z Turca cez piargske rozvodie do Kremnice, do povodia Hrona (Lamoš 1948, 25; Vozár 1983, 187; Gayer 1985, 134). V súčasnosti stále zásobuje Kremnicu vodou.

\section{Záver}

Banská Bystrica sa radí k tým vyspelým stredovekým mestám, ktoré mali v 15 . storočí zavedený vodovod. Silná nemecká pospolitost' udržiavala čulé obchodné aj kultúrne styky s materskou krajinou, ktorá preberala technické vymoženosti vyspelého západu. Obchodné, ale aj kultúrne kontakty Banskej Bystrice s Krakovom zabezpečovali majitelia baní Thurzovci a so západom augsburskí finančníci Fuggerovci (Mácelová 2005, 118). V bohatom banskom meste sa rýchlo udomácnili civilizačné výdobytky európskeho pokroku, medzi ktoré môžeme zaradit' aj technicky náročné zariadenie, akým bol gravitačný vodovod. Okrem písomných prameňov to dokazujú aj archeologické nálezy častí dreveného potrubia vyhotoveného z vydlabaného kmeňa z jedle bielej a prekrytého dubovou doskou na Námestí SNP č. 3, ako aj nálezy prevítaných rúr vodovodného potrubia na Moysesovom námestí, ktoré sme predstavili v našom príspevku. V roku 1822 drevené zásobníky na vedl'ajších uliciach mesta plánovala mestská rada nahradit' kamennými vodojemami, ale pre vysoké náklady na ich výstavbu sa od stavby upustilo (Jurkovič 2005,478 , pozn. 170). Až v 19. storočí sa začalo drevené vodovodné potrubie nahrádzat' kovovým, ako je vyznačené na pláne z roku 1829. 
Za informácie o nových a nepublikovaných nálezoch patrí pod’akovanie Mgr. Martinovi Miňovi a JUDr., Mgr. Martinovi Kvietkovi, za preklady cudzojazyčných textov Bc. Simone Brežinovej, Mgr. Petrovi Konečnému a Mgr. Imrichovi Nagyovi, PhD., za informácie o vodovode v Kežmarku PhDr. Nore Baráthovej, za mapové podklady PhDr. Otovi Tomečkovi, PhD., Jánovi Balážovi, PhDr. Valérii Solčániovej zo ŠA v Banskej Bystrici, pobočka Kremnica, a zamestnancom ŠA v Banskej Bystrici, pobočka Banská Bystrica.

\section{Pramene a literatúra}

AGRICOLA, G., 1557: Vom Berghwerck XII Bücher. Basel: Jeronymus Froben.

ALBERTI, L. B., 1960: Ksiąg dziesięć o sztuce budowania. Warszawa.

ALBERTOVÁ, H., 2009: K okolnostiam vzniku a počiatkom slobodných královských miest Zvolen, Banská Bystrica a Lubietová. In: Osídlenie Zvolenskej kotliny od včasného stredoveku do polovice 19. storočia (Tomeček, O., ed.), 49-68. Banská Bystrica.

BALÁŽ, J., 2004: Banská Bystrica v premenách času, II. vydanie. Banská Bystrica.

BARTEKOVÁ, A., 2012: Studne s výdrevou z Trnavy - Hviezdoslavovej ulice - Holzgefasste Brunnen aus Trnava in der Hviezdoslavova-Straße, AH 37, 133-141.

CDS1 II, 1987: Codex diplomaticus et epistolaris Slovaciae II (Marsina, R., ed.). Bratislava.

DOHNAL, V., 1964: Nález středověkých studní ve Veselí nad Moravou, AR XVI, 757-758, 740.

DOMENOVÁ, M., 2009: Zdravotníctvo, hygiena a údržba poriadku v meste Prešov na prelome 15. a 16. storočia - Health Care, Hygiene and Cleaning in Prešov in the Turn of the 15th and the 16th Centuries. In: Annales historici Presovienses 8/2008, 51-71. Prešov.

ĎURIŠOVÁ, M., 2013: Archeologické nálezy v uliciach Košíc - studne - Archaeological finds in the streets of Košice - wells. In: Mesto a dejiny 2 (Fedorčák, P., ed.), 40-52. Košice.

FILIP, A., 1936: O banskobystrických cirkevných i svetských stavitel'ských pamiatkach. Banská Bystrica, rkp. dokončený 1. 2. 1938.

FILLOVÁ, L.-MÁCELOVÁ, M.-ŠIMKOVIČ, M., 2002: Opevnenie mestského hradu v Banskej Bystrici v 15. a na začiatku 16. storočia - Befestigung der Stadtburg in Banská Bystrica im 15. und am Anfang des 16. Jhs., AH 27, 355-370.

GAYER, B., 1985: A turcseki erővíz-vezeték, Bányászati és Kohászati Lapok, Banyászat 118, $132-134$.

GENERSICH, CH., 1804: Merkwürdigkeiten der königlichen Freystadt Késmark. Kaschau-Leutschau I.

GOETZ, H.-W., 2005: Život ve středověku. Jinočany.

GRAUS, I., 2000: Vývoj fortifikácie Banskej Bystrice do konca 16. storočia v podmienkach špecifík pasívnej obrany stredoslovenských banských miest - Die Fortifikationsentwicklung der Stadt Banská Bystrica bis Ende des 16. Jahrhunderts unter den Spezifischen Bedingungen der passiven Verteidigung der mittelslowakischen Bergwerkstädte, Vojenská história 4, č. 1, 3-22.

GREWE, K., 1986: Zur Wasserversorgung und in Abwasserentsorgung der Stadt um 1200. In: Zur Lebensweise in der Stadt um 1200. Ergebnisse der Mittelalter-Archäologie. Zeitschrift für Archäologie des Mittelalters, Beiheft 4 (Steuer, H., Hrsg.), 275-300. Köln - Bonn.

HABOVŠTIAK, A., 1971: Stredoveké nálezy a pozostatky kamenného vodovodu pri bývalom Zoborskom kláštore v Nitre - Mittelalterliche Funde und Reste einer steinernen Wasserleitung bei dem ehemaligem Kloster auf dem Zobor in Nitra, ZbSNM, História 11, 97-120.

- 1997: K otázke vodovodných zariadení v stredovekých a včasnonovovekých kláštoroch na Slovensku Zur Frage der Wasserleitungseinrichtung in den mittelalterlichen und frühneuzeitlichen Klöstern in der Slowakei. In: Život v archeologii středověku. Sborník věnovaný Miroslavu Richterovi a Zdeňku Smetánkovi (Maříková-Kubková, J.-Klápště, J.-Ježek, M.-Meduna, P. et al., edd.), 201-206. Praha.

HAJNALOVÁ, E.-MIHÁLYOVÁ, J., 1995: Výskumná správa archeobotanická č. 13586/95, ulož. v AÚ SAV v Nitre.

- 1996: Výskumná správa archeobotanická č. 13729/96, ulož. v AÚ SAV v Nitre.

- 1997: Archeobotanické nálezy v roku 1995 - Archäobotanische Funde im Jahre 1995. In: AVANS 1997, 62-69. Nitra.

- 1998: Archeobotanické nálezy v roku 1996 - Archäobotanische Funde im Jahre 1996. In: AVANS 1996, 61-67. Nitra.

HANULIAK, V., 2007: Výskumná správa z archeologického výskumu Banskej Bystrice - Katovná, Krížna, Lazovná, Strieborné námestie - rekonštrukcia elektrorozvodných sietí. Banská Bystrica, ulož. v KPÚ Banská Bystrica, č. 2512/07/KPÚ.

HANUŠIN, J., 1986: Starý bardejovský vodovod. In: Nové obzory 28, 245-268. Košice. 
HOFFMANN, F., 1992: České město ve středověku. Praha.

HUML, V., 1975: Vodovodní sít' na Václavském náměstí v Praze v 15.-17. století, Český lid 62, 223-230.

CHYBOVÁ, H., 2009: Kroměříž zmizelá a znovu objevená aneb historie ukrytá pod dlažbou města. Kroměříž.

JORDÁNKOVÁ, H.-SULITKOVÁ, L., 1991: Zásobování města Brna vodou ve středověku (K 900. výročí první zmínky o Brně), VVM XLIII, 304-316.

JURKOVIČ, E., 2005: Dejiny král'ovského mesta Banská Bystrica - na základe poverenia predstavitel'ov mesta napísal v rokoch 1896-1922 Emil Jurkovič. Z originálu preložil I. Nagy. Banská Bystrica.

KRAJÍC, R., 1989: Středověká sladovna v Sezimově Ústí, PA LXXX, 159-187.

LAMOŠ, T., 1948: Sídelný zemepis Kremnice. Bratislava.

LICHNER, J., 1964: Stavebný charakter mestských hradieb a opevnení za čias tureckého nebezpečenstva na Slovensku, Vlastivedný časopis XIII, č. 1, 1-12.

MÁCELOVÁ, M., 1996: Požiarom zaniknutý zrubový objekt z 15. storočia v Banskej Bystrici - Der verbrannte Blockbau aus dem 15. Jahrhundert in Banská Bystrica, AH 21, 421-426.

- 1997: Výskumy v historickom jadre Banskej Bystrice - Grabungen im historischen Stadtkern von Banská Bystrica. In: AVANS 1995, 128-130. Nitra.

- 1998: Výskum na Námestí SNP v Banskej Bystrici - Grabung auf dem SNP-Stadtpatz in Banská Bystrica. In: AVANS 1997, 112-113. Nitra.

- 1999: Výsledky výskumu Mestského hradu v Banskej Bystrici - Grabungsergebnisse von der Stadtburg in Banská Bystrica. In: AVANS 1997, 111-113. Nitra.

- 2004: Stredoveké a novoveké nálezy z Banskej Bystrice - Mittelalterliche und neuzeitliche Funde aus Banská Bystrica. In: AVANS 2003, 134. Nitra.

- 2005: Kontakty Banskej Bystrice s Európou a ich odraz v materiálnej kultúre - Die Kontakten der Stadt Banská Bystrica mit Europa und ihr Widerschein in der materielle Kultur. In: Minulost' a prítomnost' Banskej Bystrice I. Zborník z vedeckej konferencie, ktorá sa konala v Banskej Bystrici v dňoch 27.-28. septembra 2005 pri príležitosti 750. výročia mesta (Nagy, I.-Graus, I., edd.), 117-126. Banská Bystrica.

MÁCELOVÁ, M.-MOSNÝ, P., 1998: Záchranný výskum na Námestí Štefana Moysesa v Banskej Bystrici-Rettungsgrabung auf dem Štefan Moyses-Stadtplatz in Banská Bystrica. In: AVANS 1996, $115-117$. Nitra.

MATUlAY, C., 1980: Mesto Banská Bystrica. Katalóg administratívnych a súdnych písomností. /1020/ 1255-1536. Bratislava.

MATUNÁK, M., 1928: Z dejín slobodného a hlavného banského mesta Kremnice. Kremnica.

MERTA, D.-PEŠKA, M.-ZŮBEK, A., 2004: K zásobování města Brna vodou z Kartouz, Archeologia technica $15,70-77$.

MÉSZÁROSOVÁ, K., 1980: Stredoveké nálezy z Trnavy - Mittelalterliche Funde aus Trnava. In: AVANS 1979, 140-142. Nitra.

- 1980a: Stredoveké nálezy zo stredovekej Trnavy. In: Muzeálny spravodaj. Západoslovenské múzeum Trnava, 45-48. Trnava.

MIŇO, M.-BREZŇANOVÁ, G.-FRATRIČOVÁ, M., 2008: Nálezová správa z archeologického výskumu meštianskeho domu na Námestí SNP č. 1 - radnica, Banská Bystrica (parcela č. 1449/1 - dvorný trakt), ulož. v KPÚ Banská Bystrica.

MUZYCZUK, A.-GANCARSKI, J., 2003: Krosno, parva Cracovia. Badania wykopaliskowe na Rynku. Krosno.

NAGY, Á., 2003: Brunnen und Zisternen im mittelalterlichen Ungarn. In: Anteus 26, 343-411. Budapest.

NAGY, P.-ČURNÝ, M., 2011: Stredoveké a novoveké keramické potrubia zo Slovenska - Mittelalterliche und neuzeitliche Keramikleitungen aus der Slowakei, AH 36, 541-555.

PAVELČÍK, J., 1955: Nálezy ze 13. století z Uherského Brodu, ČNM CXXIV, 143-148.

PETRÁŇ, J. a kol., 1985: Dějiny hmotné kultury I (2). Praha.

PETRÁS̆, M., 1993: Dejiny pivovarníctva, sladovníctva a chmeliarstva na Slovensku. In: Z dejín pivovarníctva, sladovníctva a chmeliarstva na Slovensku. Zborník z prvej celoslovenskej konferencie Pivovarníctvo, sladovníctvo a chmeliarstvo na Slovensku v minulosti (Petráš, M., ed.), 7-12. Trnava.

PISOŇ, Š. a kol., 1968: Slovník obcí Banskobystrického okresu. Banská Bystrica.

POLLA, B.-VALLAŠEK, A., 1991: Archeologická topografia Bratislavy. Bratislava.

RAITSITS, L., 1896: Beszterczebánya sz. Kir. Város egészégügye különös tekintettel az utolsó évtizedbeli assanáló munkalataira. Banská Bystrica.

RATKOŠ, P., 1957: Dokumenty k baníckemu povstaniu na Slovensku (1525-1526). Bratislava.

- 1964: Povstanie baníkov na Slovensku (1525-1526). Bratislava. 
- 1964a: K topografii Banskej Bystrice v čase baníckeho povstania v rokoch 1525-1526. In: Historické štúdie IX, 103-120. Bratislava.

SIKLÓSI, G., 2003: Die Wasserversorgung und das Kanalsystem im mittelalterlichen Székesfehervár (Stuhlweißenburg). In: ANTAEUS 26, 217-244. Budapest.

SKRUŽNÝ, L., 1995: Zdroje vody - místa pohanských a křest’anských kultů - zdroje pitné a užitkové vody, jejich úprava, rozvod a možné zdroje ikonografického materiálu - Wasserquellen - Orte der heidnischen und christlichen Kulte Quellen des Trink- und Gebrauchtswassers und Möglichkeiten der Ikonographie, AH 20, 631-644.

SLIVKA, M., 1986: Obraz stredovekého mesta na Slovensku, Vlastivedný časopis XXXV, č. 1, 64-66.

SOWINA, U., 2009: Woda i ludzie w mieście późnośredniowiecznym i wczesnonowożytnym. Ziemie polskie z Europą w tle. Warszawa.

ŠA v BB, pobočka BB, fond MBB, Fasc. 915/26, 40-42.

ŠA v BB, pobočka BB, fond MBB, Mp-87a, ev. č. 2804. A.

ŠA v BB, pobočka BB, fond MBB, Mp-35j.

ŠA v BB, pobočka BB, Protocol praetoriale z r. 1543-1550.

ŠA v BB, pobočka BB, Protocol praetoriale z r. 1577.

ŠA v BB, pobočka BB, Protocole praetoriale z r. 1716.

ŠA v BB, pobočka BB, Protocol praetoriale z r. 1727.

ŠEBESTA, P., 2009: Hygiena ve středověkém Chebu - Hygiene im mittelalterlichen Eger (Cheb), AH 34, $815-833$.

ŠIROKÝ, R., 2000: Pitná, užitková a odpadní voda v českých městech ve středověku a raném novověku. Stav a perspektivy archeologického poznání - Wasserversorgung und Wasserentsorgung in den böhmischen Städten des Mittelalters und der frühen Neuzeit. Stand und Perspektivender archäologischen Forschung, PA XCI, 345-410.

ULIČNÝ, F., 2006: Mesto Banská Bystrica okolo roku 1255 - Die Stadt Banská Bystrica um das Jahr 1255. In: Minulost' a prítomnost' Banskej Bystrice I. Zborník z vedeckej konferencie, ktorá sa konala v dňoch 27.-28. septembra 2005 pri príležitosti 750. výročia mesta (Nagy, I.-Graus, I., edd.), 5-14. Banská Bystrica.

ULIČNÝ, M., 2000: Archeologický prieskum počas rekonštrukčných prác v centre Prešova - Archäologische Erkundung während der Rekonstruktionsarbeiten im Stadtzentrum von Prešov. In: AVANS 1999, 140-141. Nitra.

UŠIAK, P., 1996: Nález dreveného potrubia v Banskej Bystrici - Fund einer hölzernen Leitung in Banská Bystrica. In: AVANS 1994, 177. Nitra.

VELÍMSKÝ, T., 1976: Archeologický výzkum historického jádra Mostu v roce 1974 - Stadtkernforschung in Brüx im Jahre 1974, AH 1, 197-204.

VENDTOVÁ, V., 1966: Studne z doby vel'komoravskej v Pobedime, SlArch XIV, 417-438.

VOZÁR, J., 1983: Zlatá kniha banícka - Das goldene Bergbuch. Bratislava.

ZACHAR, J., 2009: Archeologický výskum na Hornej ul. č. 2 v Banskej Bystrici (K významu vnútro dvorov pre poznanie stredovekej a novovekej materiálnej kultúry mesta) - Die archäologische Grabung in der Oberen Gasse (Horná) Nr. 2 in Banská Bystrica (Zur Bedeutung der Innenhöfe beim Verständnis der mittelalterlichen und neuzeitlichen Sachkultur der Stadt), AH 34, 285-300.

ZACHAR, J.-MÁCELOVÁ, M., 2007: Výskumná dokumentácia z archeologického výskumu z lokality Banská Bystrica, intravilán - centrum, Lazovná ulica, ulož. na Katedre histórie Filozofickej fakulty UMB v Banskej Bystrici, ev. č. 7/2007.

- 2008: Výskumná dokumentácia z archeologického výskumu z lokality Banská Bystrica, intravilán, Horná ul. č. 2-4, ulož. na Katedre histórie Filozofickej fakulty UMB v Banskej Bystrici, ev. č. 10/2008.

ŽILÁK, J., 1993: Pivovarníctvo v Banskej Bystrici. In: Z dejín pivovarníctva, sladovníctva a chmeliarstva na Slovensku. Zborník z prvej celoslovenskej konferencie Pivovarníctvo, sladovníctvo a chmeliarstvo na Slovensku v minulosti (Petráš, M., ed.), 68-74. Trnava.

\section{Zusammenfassung}

\section{Das Wasserleitungssystem von Banská Bystrica in Mittelalter und Neuzeit im Lichte der archäologischen Funde und schriftlichen Quellen}

Die am Zusammenfluss des Flusses Gran (Hron) und des Baches Bystrica gelegene, ursprüngliche slawische Siedlung Bystrica begann sich nach Ankunft der von Béla IV. nach dem 
Mongoleneinfall eingeladenen deutschen Kolonisten (Sachsen) zu einer bedeutenden Bergbaustadt zu wandeln. Der Stadtbildungsprozess wurde durch die vom Herrscher 1255 erteilten Privilegien beschleunigt. Ab dem Jahr 1495 hatte die Thurzo-Fuggersche Handelsgesellschaft dort ihren Sitz, die den Kupferhandel weltweit beherrschten. In der reichen Bergbaustadt bürgerten sich die Errungenschaften des europäischen Fortschritts ein, zu denen wir auch ihr durch Schwerkraft betriebenes Wasserleitungssystem zählen. Neben zahlreichen schriftlichen Quellen, die sich auf dessen Bau und Instandsetzung beziehen, trugen auch die archäologischen Grabungen der letzten zwanzig Jahre zu seiner Wiederentdeckung bei. Beim Austausch der Versorgungsnetze wurden auf mehreren städtischen Parzellen (Abb. 1) Relikte von alten mittelalterlichen und neuzeitlichen Brunnen (Abb. 2-5), von einer Wasserleitung aus Holz sowie von Kanalisationsanlagen entdeckt. Zustand und Verteilung der Brunnen ist auf einer Karte aus dem Jahr 1895 verzeichnet (Abb. 6). Den schriftlichen Quellen nach wurde das Wasser bereits ab Ende des 15. Jahrhunderts durch eine Gravitationswasserleitung von der in der Siedlung Sásová liegenden Quelle in die Stadt Banská Bystrica geleitet. Der Hauptwasserspeicher befand sich im Areal der Stadtburg, von wo aus es in die Speicher und einzelnen Häuser geleitet wurde, die sich auf dem Marktplatz und in den angrenzenden Straßen befanden (Abb. 7). Mit diesem Wasser wurde auch der Graben der Stadtburg gefüllt. Auf einer Karte aus dem Jahr 1786 ist die damals noch übriggegliebene Wasserfläche des Wassergrabens eingezeichnet, der nach einem Brand im Jahr 1761 zugeschüttet worden war (Abb. 8). Auf dem Platz des Slowakischen Nationalaufstandes hat man im Jahr 1995 im Hoftrakt von Haus Nr. 3 bei einer archäologischen Grabung ein mittelalterliches Objekt aus dem 15. Jahrhundert, das im Jahr 1500 abbrannte, und eine neuzeitliche Architektur entdeckt, die aus der Zeit zwischen dem 15.-17. Jahrhundert stammt. (Abb. 9-11). In einer Tiefe von 70-80 cm war die mittlere Fläche des Sondierschnitts mit einer einheitlichen Geröllschicht gepflastert, unter welcher man ein gut erhaltenes, $35 \mathrm{~cm}$ breites Eichenbrett fand, das an der Wasserleitung auflag und sie bedeckte. Die Leitung war aus $3 / 4$ des Stammumfangs einer Weißtanne ausgehöhlt worden. Die Innenseite der Rinne war mit einem organischen Stoff getränkt, der ein Durchsickern des Wassers verhindern sollte. Die hölzerne Leitung war mit Quer- und Längsbrettern gegen ein Verrutschen gesichert. Mit der Technik des Aushöhlens von Holzstämmen beschäftigt sich G. Agricolas mit kolorieren Illustrationen versehene Monographie Vom Bergkwerck 12 Bücher (Abb. 12). Im Südteil des Sondierschnitts entdeckte man eine Abflussrinne, die zur Ableitung des Wassers von der Parzelle diente (Abb. 13). Beim Austausch der Versorgungsnetze auf dem Štefan-Moyses-Platz entdeckte man vor den Häusern Nr. 8-5 in einer Tiefe von $110 \mathrm{~cm}$ eine Wasserleitung, die aus durchbohrten Holzröhren hergestellt worden war (Abb. 14). Die Länge der durch einen Mechanismus beschädigten Leitung betrug ca. $3 \mathrm{~m}$ (Abb. 15). Über die bis in die zweite Hälfte des 19. Jahrhunderts in Betrieb gewesenen, aus den Siedlungen Kostiviarská und Sásová geführten Stränge des Gravitationswasserleitungssystems gibt ein Wasserleitungsplan aus dem Jahr 1829 Auskunft. Darin sind auch neue hölzerne Wasserleitungsanschlüsse für die einzelnen Häuser auf dem Hauptplatz eingezeichnet (Abb. 16). Die unterirdisch geführte Wasserleitung ist auf einer Katasterkarte der Siedlung Kostiviarská aus dem Jahr 1882 eingezeichnet (Abb. 17). Auf mehreren Parzellen hat man auch Teile der Kanalisation entdeckt. Diese bestanden aus Steinplatten, die kleine parallele Steinwände abdeckten. Bei der Sanierung der Versorgungsnetze auf dem Platz des Slowakischen Nationalaufstandes entdeckte man den Teil einer hölzernen Wasserleitung, mit welcher wahrscheinlich das Wasser des Springbrunnens abgeleitet wurde. Banská Bystrica zählt zu den hochentwickelten mitteleuropäischen Städten, die im 15. Jahrhundert bereits über ein Wasserleitungssystem verfügten.

PhDr. Marta Mácelová, PhD., Katedra histórie Filozofickej fakulty Univerzity Mateja Bela, Tajovského 40, SK 97401 Banská Bystrica, Slovenská republika, marta.macelova@umb.sk 
